\title{
Post-emergence seedling damage due to vertebrate pests and its impact on soybean establishment
}

\author{
Jay Ram Lamichhane ${ }^{\text {Corresp. } 1}$ \\ 1 INRAE, Université Fédérale de Toulouse, UMR 1248 AGIR, F-31326, Castanet-Tolosan, France \\ Corresponding Author: Jay Ram Lamichhane \\ Email address: jay-ram.lamichhane@inra.fr
}

The quality of field crop establishment is an indicator of the productivity and yield quality of a given crop. Several biotic and abiotic factors, as well as cropping practices, affect the quality of field crop establishment. More specifically to soybean, recent studies quantified pre-emergence seedling losses and identified the associated causes of non-emergence. However, little is known about post-emergence seedling damage, mainly due to vertebrate pests, which represent an important problem for growers. A 2-year field observation was conducted to quantify near- and post-emergence seedling damage due to vertebrate pests. The common wood pigeon (Columba palumbus) and the European hare (Lepus europaeus) were associated with this kind of damage. The characteristic damage due to the common wood pigeon consisted of either partially-damaged cotyledons during emergence or completely uprooted seedlings at emergence. In contrast, damage due to the European hare consisted of chewed seedling or seedling parts. There was significant effect of year $(p<0.001)$ on the final rates of post-emergence seedling damage due to the wood pigeon but not on those due to the European hare. The final rates of post-emergence damage due to the wood pigeon were higher (32\% for 2018 and $22 \%$ for 2020 ) compared with those owing to the European hare (18\% for 2018 and $17 \%$ for 2020). The severity of damage due to vertebrate pests was related to the type of seedling damage that, in turn, affected the capacity of soybean to compensate for post-emergence seedling damage. 
1 Post-emergence seedling damage due to vertebrate pests and its impact on soybean

2 establishment

3 Jay Ram Lamichhane

4 INRAE, Université Fédérale de Toulouse, UMR 1248 AGIR, F-31326 Castanet-Tolosan,

5 France France

$6 \quad *$ Corresponding author: jay-ram.lamichhane@inrae.fr

7

$8 \quad$ Tel: +33 (0)5 612852 50; Fax: +33(0)5 61285537

9 Abstract

The quality of field crop establishment is an indicator of the productivity and yield quality of a given crop. Several biotic and abiotic factors, as well as cropping practices, affect the quality of field crop establishment. More specifically to soybean, recent studies quantified pre-emergence seedling losses and identified the associated causes of non-emergence. However, little is known about post-emergence seedling damage, mainly due to vertebrate pests, which represent an important problem for growers. A 2-year field observation was conducted to quantify near- and post-emergence seedling damage due to vertebrate pests. The common wood pigeon, Columba palumbus (Linnaeus), and the European hare, Lepus europaeus (Pallas), were associated with this kind of damage. The characteristic damage due to the common wood pigeon consisted of either partially-damaged cotyledons during emergence or completely uprooted seedlings at emergence. In contrast, damage due to the European hare consisted of chewed seedling or seedling parts. There was significant effect of year $(p<0.001)$ on the final rates of post-emergence seedling damage due to the wood pigeon but not on those due to the European hare. The final rates of post-emergence damage due to the wood pigeon were higher (32\% for 2018 and $22 \%$ for 2020 ) compared with those owing to the European hare (18\% for 2018 and $17 \%$ for 2020). The severity of damage due to vertebrate pests was related to the type of seedling damage that, in turn, affected the capacity of soybean to compensate for post-emergence seedling damage.

Keywords : animal damage, bird damage, damage estimates, Glycine max 


\section{Introduction}

32

Soybean (Glycine max (L.) Merr.), represents one of the most important leguminous crops worldwide, which is mainly grown for the quality of its protein both for food and feed purposes (Masuda and Goldsmith, 2009). In the European Union (EU), an important decrease in soybean acreage has been observed in the last two decades, leading to several socio-economic and environmental concerns (Labalette et al., 2010). The EU produces only a small fraction of soybean (2.6 Mt that is equivalent to $<0.5 \%$ of the global production) with over $85 \%$ of the grain consumed in the EU being imported from the American continent (FAOSTAT, 2018). More specifically to France, there is a huge gap between the quantity of soybean produced ( $<0.5 \mathrm{Mt}$ ) and consumed ( $>5 \mathrm{Mt}$ ) annually (FOP, 2018). To fill this gap, public policy in the EU aims at increasing the soybean acreage with three-fold objectives: reducing dependence on genetically-modified soybean imported for feed purpose, satisfying the demand for locally produced non-genetically modified soybean for human consumption, and contributing toward the transition to more sustainable agricultural systems (Berschneider, 2016).

Crop establishment consists of three sub-phases: seed germination, seedling emergence, and early seedling growth (Aubertot et al., 2020). Recent studies conducted in France reported that several biotic and abiotic stresses can affect the quality of soybean establishment (Lamichhane et al., 2020a, 2020b). In particular, mechanical obstacles such as soil aggregates and soil surface crusts have been reported to cause seedling emergence losses while soil-borne pests and pathogens were not a major cause of non-emergence. Nevertheless, these studies did not focus on evaluating post-emergence seedling losses due to biotic stresses in general and those due to vertebrate pests in particular, which were frequently observed across the experimental sites. Post-emergence seedling losses due to vertebrate pests represent an important problem for many field crops, leading to severe economic losses across the globe (Firake et al., 2016; Giunchi et al., 2012; McKee et al., 2020; Nasu and Matsuda, 1976). 
58 The objective of this study was to quantify post-emergence seedling damage of soybean 59 due to vertebrate pests at the scale of an experimental site with different spatial

60

61

62

63

64

65

66

67

68

69 replications. This is important to understand whether and to what extent this damage can affect the quality of soybean establishment across the study site. This information may provide important insight for future research that aims to develop and implement cropping practices that limit access to these pests into soybean fields, as well as to design cropping systems that are less vulnerable to vertebrate pest attacks. Collectively, all of this will improve the quality of crop establishment and the competitiveness of the crop in the cropping system.

\section{Materials and methods}

2.1. Desciption of the study site and experimental design

Field observations were carried out for two years (2018 and 2020) in Auzeville experimental station of INRAE (Institut national de recherche pour l'agriculture, l'alimentation et l'environnement; $43.53^{\circ} \mathrm{N}, 1.58^{\circ} \mathrm{E}$ ), southwest of France. The observations were conducted across different field plots of the same study site for the two years. For each year, three field plots grown with the same soybean cultivar (ES Pallador) were chosen to represent spatial replication with regard to the distance from the residential and non-agricultural areas (Figure 1). The latter areas are characterized by the Midi canal with a small strip of bushes, trees and hedgerow that represent a roosting zone for vertebrate pests. Plot location is an important feature as it may affect the type and abundance of vertebrate pests, and associated post-emergence seedling damage (Sausse and Lévy, 2020).

Detailed information on the experimental plots are reported in Table 1. The size of the experimental plots ranged from 0.50 and 2.40 ha and the sowing date was mid-May as generally practiced by growers in the region. The plots were sown with untreated soybean seeds at $3 \mathrm{~cm}$ sowing depth, and 40 seeds $\mathrm{m}^{-2}$ planting density with $50 \mathrm{~cm}$ inter-row distance, which corresponds to standard practices of farmers in the region (Lamichhane et al., 2020a, 2020b). None of the experimental plots were protected by fences or nylon nets to allow free access to vertebrate pests. 
86 The design used for this observational study at the spatial replication scale (i.e. a field plot)

87 is presented in Figure 2. Each spatial replication included four microplots (25 x $3 \mathrm{~m})$, and

88

89

90

91

92

93

94

95

96

97 each microplot contained four diagonal rows (each 2 linear meters). The countings were performed on 16 rows/plot that represented replicates.

\subsection{Field observations and countings}

The rate of seedling emergence was determined by the ratio between the number of emerged seedlings at VE stage (i.e. when cotyledons are above the soil surface; Fehr and Caviness (1977)) and the sowing density. At each observation, the total number of emerged seedlings with or without damage was counted. For damaged seedlings, the type of damage (i.e. partial-damage of cotyledons, total damage due to uprooting of seedlings, or chewed seedlings or seedling parts) and the associated vertebrate pest(s) were identified by direct preliminary field observations and the literature reports (Firake et al., 2016). Preliminary surveys were based on several years of field observations by technicians who regularly monitored soybean plots every week at the crop establishment phase. This information allowed us to rule out any post-emergence damage due to other types of vertebrates than those reported here. The countings of post-emergence damage were performed when cotyledons were nearly at the VE stage (i. e. when cotyledons begin to pierce the seedbed surface), and continued across the VC (cotyledon stage where unifoliate leaves are unrolled sufficiently so that the leaf edges are not touching) and V1 (first node stage with fully developed leaves are present at unifoliate nodes) growth stages; Fehr and Caviness, (1977)). These stages were chosen as post-emergence damage due to vertebrate pests

mainly occur at these phases (Firake et al., 2016). This was further confirmed by preliminary observations during which important seedling losses due to vertebrate pests were observed. The countings of post-emergence seedling losses were made every two days for aproximately two weeks. The countings continued until reaching a plateau with no new damaged seedlings for three consecutive countings.

\subsection{Statistical analyses}

The rate of seedling emergence was determined by using the following formula: 
Where TES is the total number of emerged seedlings and SD is the sowing density.

117 The rate of post-emergence damage was calculated using the following formula:

$$
\text { Post-emergence damage }(\%)=100 \times \frac{T D S d t}{T E S}
$$

119

120

121

122

123

124

125

126

127

128

129

130

131

132

133

134

135

136

137

138

139

Where TDSdt is the number of damaged seedlings per damage type (i.e. partially-damaged cotyledons, uprooted seedlings, or chewed seedlings or seedling parts).

The counted number of plants was transformed in percentage, and the data did not meet the normality assumption. Therefore, a non-parametric Kruskall-Wallis test was applied to test for differences between years. The analysis was performed using the $\mathrm{R}$ software (Hothorn and Everitt, 2009).

\section{Results}

\subsection{Soybean emergence rates}

Final emergence rates of soybean over the two years are presented in Table 2. The emergence rates were $82 \pm 12$ and $72 \pm 13$ for 2018 and 2020, respectively. There was significant effect of year $(p<0.001)$ on the final rates of seedling emergence.

3.2. Vertebrate pests and characteristics of post-emergence seedling damage

The common wood pigeon, Columba palumbus (Linnaeus), and the European hare Lepus europaeus (Pallas), were two key vertebrate pests regularly observed in our experimental plots. None of these pests caused pre-emergence damage to soybean seedlings. The postemergence damage caused by these pests could be recognized based on the characteristics of the damage observed in the field. Seedling damage due to common wood pigeon consisted of either partial damage on the cotyledons as soon as they began to pierce from the seedbed surface (Figure 3a) or uprooting of seedlings from the seedbed (Figure 3b). No seedling damage due to common wood pigeon was observed after the VC stage. In contrast, seedling damage due to wild hares was observed between the VC and V1 stage, 
140 which consisted of chewed seedlings (Figure 3c, d). Unlike common wood pigeon, wild

141 hares did not cause any uprooting of seedlings.

142 3.3. Severity of post-emergence seedling damage due to vertebrate pests

143 The final rates of post-emergence seedling damage, based on individual characteristics

144 observed in the field, are presented in Table 3. There was significant effect of year $(p<$ 145 0.001) on the post-emergence seedling damage due to the wood pigeon (i.e. partially146 damaged cotyledons and uprooted seedlings). In contrast, no statistically significant 147 differences $(p>0.05)$ were found in the post-emergence seedling damage due to the 148 European hare between the two years. Collectively, the final rates of post-emergence 149 seedling damage, due to both vertebrate pests, significantly differed $(p<0.001)$ between 150 the two years. The rates of post-emergence damage were similar over the two years and 151 they ranged from 8 to 12\%, 14 to $20 \%$, and 17 to $18 \%$ for partially-damaged cotyledons, 152 uprooted seedlings and chewed seedlings, respectively. The final rates of post-emergence 153 damage were $50 \%$ and $39 \%$ in 2018 and 2020 , respectively.

3.4. Recovery ability of damaged seedlings

155

156

157

158

159

160

161

162

163

164

165

166

167

The capacity of damaged seedlings to recover was dependent on the type and intensity of the initial damage caused by vertebrate pests. No seedling growth recovery occurred leading to severe damage and crop emergence failure when cotyledons were entirely damaged during emergence (i.e. when cotyledons still touch the seedbed surface) or completely uprooted by common wood pigeon (Figure 4). In contrast, seedlings recovered their growth by developing new leaves beginning from the nodes, when cotyledons were partially damaged at the near VE stage or when seedlings were partially damaged above the first node at the VE to V1 stage (Figure $\mathbf{5} \mathbf{a}, \mathbf{b}$ ).

\section{Discussion}

To the best of the author's knowledge, this is the first study in France and Europe that attempts at quantifying post-emergence damage of soybean due to vertebrate pests via field observations and countings. Previous studies reported crop damage due to vertebrate pests, with millions of dollars of crop losses (Elser et al., 2019; Gebhardt et al., 2011; 
168 Swanepoel et al., 2017). However, these losses were mainly related to advanced stages of 169 the crop cycle (i.e. the near harvesting phase) including grain or fruit feeding. In contrast, 170 only little is known on the impact of birds and wild animals on the very early stage of field 171 crops (i.e. seed germination, seedling emergence, and early development stages) that can 172 jeoparadize the quality of field crop establishment. A few studies assessed seed and 173 seedling damage that occurred before the crop establishment phase on corn (Furlan et al., 174 2017; Khan et al., 2015; Wise, 2018), wheat (Kennedy and Connery, 2008; Khan et al., 175 2015), oilseed rape (Schillinger and Werner, 2016), speciality crops (Werner et al., 2015), 176 and soybean (Firake et al., 2016).

177 178

A previous study (Firake et al., 2016) on soybean showed that the rate of seed and seedling damage due to Colombidae is strictly dependent on the crop growth stage. Indeed, the authors highlighted that severe damage occurred at the seed germination, seedling emergence, and green cotyledon stages, followed by only moderate to low damage occurred at the V1 stage, and almost negligeble damage after this stage. Nevertheless, there was no pre-emergence damage due to Colombidae across our study site and that the initial damage commenced to appear nearly at the VC stage, when cotelodons started to pierce the seedbed surface. This difference could be due to many factors including the bird species causing damage, geographical region of the study, the type of landscape, the distance of the experimental site from the residential area, sowing dates, and the type of seedbed preparation. In the study by Firake et al. (2016), the spotted dove, Spilopelia chinensis (Scopoli), and occasionally feral pigeon, Columba livia (Gmelin), were associated with heavy damage in newly sown soybean fields in northeast India. In contrast, the common wood pigeon and the European hare were associated with post-emergence damage in this study that was carried out in southwestern France and with much earlier sowing dates (i.e. mid-May). This might have affected the bird types involved in seedling damage.

In addition to the common wood pigeons, post-emergence seedling damage due to the European hares was observed during this study. A recent research from central India (Bayani et al., 2016) reported damage to soybean and many other crops due to wild mammalian herbivores, including hares, although the damage regarded much advanced stages of the crop. In general, the type of wild mammalian herbivores and their associated 
198 damage to crops depend also on the landscape around the field including field-edge habitat

199 and distance from residential area (Sellers et al., 2018).

200 Here, post-emergence seedling damage due to the common wood pigeons was

201 distinguished from that due to the European hares based on the type of damage and crop

202 growth stage. Indeed, the former caused seedling damage at earilier stage than do the latter

203 and the damage type was generally distingushable. Nevertheless, there were a few cases of

204 mixed post-emergence seedling damage caused by both vertebrate pests on the same

205 seedlings (e.g. partially damaged cotyledons recover their growth but they are later

206 attacked by the European hares), which were difficult to distinguish. Future studies are

207 needed to make wider observations of different vertebrate pests on different crop species

208 and the associated seedling damage, which may help precisely estimate seedling damage

209 due to each specific pest cropwise.

210 In this study, the temporal (i.e. year) effect was significant on the post-emergence damage 211 due to the common wood pigeon but not on that due to the European hare. This contrast is 212 interesting and might be due to the capacity of these two pests to move at different scales.

213 For example, the common wood pigeon, as many other birds, is very mobile animal, capable 214 of flying at a large scale within a short period of time. Consequently, the post-emergence 215 damage of a given crop due to birds is determined by three spatial scales (Sausse and Levy, 216 2020): i) the regional scale where they decide to settle for the season (nesting aimed at 217 causing post-emergence damage) that will determine a pool of birds causing post218 emergence damage; ii) the landscape scale, where they select the places to feed as part of 219 their daily activity; and iii) the plot scale where they look for food items. In contrast to 220 birds, the movement of the European hare remains limited within a restricted area that 221 may explain the similar level of post-emergence damage occurred between the two years of 222 study. Future studies that take into account a wider spatio-temporal replication of field 223 plots are needed to better understand in this regard.

224 Previous studies reported seed and seedling damages due to Corvidae on many field crops 225 including corn and wheat (Kennedy and Connery, 2008; Khan et al., 2015; Wise, 2018). 226 While Corvidae were occasionally observed across the experimental site, no important 
227 damage due to them was found on soybean seed or seedlings. Nevertheless, these birds

228 were more commonly found across neighbouring field plots sown with corn and sunflower.

229 It is possible that Corvidae damage on soybean was negligible because these birds prefer

230 sunflower or corn rather than soybean. However, this study did not investigate the 231 potential correlation between the crop species grown in neighbouring plots and the type 232 and abundance of bird species that needs further exploration.

233 Post-emergence seedling damage due to vertebrate pests can cause severe yield losses. 234 However, the estimation of these losses is extreamly difficult for several reasons. First, the 235 correlation between post-emergence seedling damage due to vertebrate pests and 236 subsequent yield losses are not necessarily linear (Brown et al., 2007). This is especially 237 true for crops that can compensate emergence losses and seedling damage due to their 238 tillering (e.g. wheat) and branching capacity as well as indeterminate or semi-determinate 239 growth (e.g. soybean). In contrast, the correlation between post-emergence seedling damage and subsequent yield losses could be linear for those crops that do not have any compensation ability following early stage damage, such as maize, sugar beet or sunflower. Therefore, as suggested previously (Swanepoel et al., 2017), the impact of any stress and the level of damage at the seedling stage should be viewed as damage and not necessarily as crop losses for the first group of crops. In contrast, this level of damage may correspond to subsequent crop losses for crops without any compensation ability. This means that, seedling damage for the second group of crops can be proposed as a good indicator of crop losses. A previous study reported that for temperate crops, $10 \%$ seedling losses resulted in 9\% crop losses at harvest (Myllymaki, 1989). This study showed that the level of compensation of soybean to seedling damage depends on the seedling growth stage and the type of the damage itself. When cotyledons were completely damaged before the development of first nodes (i.e. before the V1 stage), seedlings most often were unable to recover. In contrast, when seedlings were partially damaged at the V1 stage and above the first node, they could develop new leaves beginning from the first nodes which, however, led to a very heterogeneous growth stage of the crop.

\section{Conclusions}


256 The present study provides a first estimation of seedling damage due to the common wood 257 pigeon and the European hare that are key vertebrate pests affecting nearly emerged and

258

259

260

261

262

263

264

265

266

267

268

269

270

271

272

273

274

275

276

277

278

279

280

281

282

283

284

285

286

emerged soybean seedlings in southwestern France. Although the rates of soybean seedling damage due to vertebrate pests were relatively high, most often, the crop was able to partially compensate this damage through its branching capacity and semi-determinate or indeterminate growth habit. However, in some cases, post-emergence damage may directly affect soybean yield especially when cotyledons are entirely damaged during emergence (i.e. when cotyledons still touch the seedbed surface) or completely uprooted by birds.

The results presented in this study were based on 2-year field observations at a small-scale spatial replication. The lack of a large-scale spatial replication and the number of crop genotype (only one) considered represent a limit of this study. The heterogeneous size of the plots used as spatial replication consititutes another drawback of this study. Indeed, the size of a plot determines the available edge habitat that, in turn, may affect the extent and type of post-emergence damage. Future studies that take into account different study sites and crop genotypes, heterogeneous landscape composition, and sowing dates are needed to provide insights into potential correlations between the quality of soybean establishment and grain yield, both in terms of quality and quanity. Finally, the database generated by this study can be used to feed a qualitative model called CESIM (Crop Establishment SIMulator; Lamichhane et al., 2020c). This model, in addition to emergence losses due to abiotic and biotic factors, and cropping practices, also takes into account the impact of post-emergence seedling damage on the quality of field crop establishment.

\section{Acknowledgements}

The author thanks: Didier Raffaillac for his kind availability and feedback provided on the research topic during field observations, and l'UMT PACTOLE for supporting the initiative to promote the results presented in this paper.

\section{References}

Aubertot, J.-N., Deguine, J.-P., Lamichhane, J.R., Robin, M.-H., Sarthou, J.-P., Steinberg, C., 2020. Vers une protection agroécologique des cultures en phase d'implantation, in: Réussir l'implantation Des Cultures. pp. 107-134 (in French).

Bayani, A., Tiwade, D., Dongre, A., Dongre, A.P., Phatak, R., Watve, M., 2016. Assessment of 
Crop Damage by Protected Wild Mammalian Herbivores on the Western Boundary of Tadoba-Andhari Tiger Reserve (TATR), Central India. PLoS One 11, e0153854e0153854. https://doi.org/10.1371/journal.pone.0153854

Berschneider, J., 2016. Chances and Limitations of European Soybean Production: Market Potential Analysis; Universität Hohenheim: Stuttgart, Germany.

Brown, P.R., Huth, N.I., Banks, P.B., Singleton, G.R., 2007. Relationship between abundance of rodents and damage to agricultural crops. Agric. Ecosyst. Environ. 120, 405-415. https://doi.org/https://doi.org/10.1016/j.agee.2006.10.016

Elser, J.L., Lindell, C.A., Steensma, K.M.M., Curtis, P.D., Leigh, D.K., Siemer, W.F., Boulanger, J.R., Shwiff, S.A., 2019. Measuring bird damage to three fruit crops: A comparison of grower and field estimates. Crop Prot. 123, 1-4. https://doi.org/https://doi.org/10.1016/j.cropro.2019.05.010

FAOSTAT, 2018. http://www.fao.org/faostat/en/\#data/TP.

Fehr, W.R., Caviness, C.E., 1977. Stages of Soybean Development. Ames, IA: Agriculture and Home Economics Experiment Station, Iowa State University of Science and Technology. Spec. Rep. 80: 11.

Firake, D.M., Behere, G.T., Chandra, S., 2016. An environmentally benign and cost-effective technique for reducing bird damage to sprouting soybean seeds. F. Crop. Res. 188, 7481. https://doi.org/https://doi.org/10.1016/i.fcr.2016.01.008

Furlan, L., Vasileiadis, V. P., Chiarini, F., Huiting, H., Leskovšek, R., Razinger, J., Holbe, I.J., Sartori, E., Urek, G., Verschwele, A., Benvegnù, I., Sattin, M., 2017. Risk assessment of soil-pest damage to grain maize in Europe within the framework of Integrated Pest Management. Crop Prot.

97:52-59 http://www.sciencedirect.com/science/article/pii/S0261219416303520.

FOP, 2018. http://www.fopoleopro.com/la-filiere-soja-en-france/.

Gebhardt, K., Anderson, A.M., Kirkpatrick, K.N., Shwiff, S.A., 2011. A review and synthesis of bird and rodent damage estimates to select California crops. Crop Prot. 30, 11091116. https://doi.org/https://doi.org/10.1016/j.cropro.2011.05.015

Giunchi, D., Albores-Barajas Y.V, Baldaccini N.E., Vanni, L., Soldatini, C., S., 2012. Feral Pigeons: Problems, Dynamics and Control Methods, Integrated PestManagement and Pest Control Current and Future Tactics Dr. Sonia Soloneski(Ed.), ISBN: 978-953-51301 0050-8, InTech

Hothorn, T., Everitt, B., 2009. A Handbook of Statistical Analyses Using R, Second Edition, A Handbook of Statistical Analyses Using R. https://doi.org/10.1201/9781420079340

Kennedy, T.F., Connery, J., 2008. An Investigation of Seed Treatments for the Control of Crow Damage to Newly-Sown Wheat. Irish J. Agric. Food Res. 47, 79-91.

Khan, H.A., Javed, M., Zeeshan, M., 2015. Damage assessment and management strategies for house crow (Corvus splendens $\mathrm{L}$ ) on the seedling stages of maize and wheat in an 
irrigated agricultural farmland of Punjab, Pakistan. J. Entomol. Zool. Stud. 3, 151-155.

326

327

328

329

330

331

332

333

334

335

336

337

338

339

Labalette, F., Bourrel, C., Jouffret, P., Lecomte, V., Quinsac, A., Ledoux, S., 2010. Panorama et futur de la filière du soja français. OCL 17, 345-355 (in French).

Lamichhane, J R, Constantin, J., Schoving, C., Maury, P., Debaeke, P., Aubertot, J.-N., Dürr, C., 2020a. Analysis of soybean germination, emergence, and prediction of a possible northward establishment of the crop under climate change. Eur. J. Agron. 113, 125972. https://doi.org/10.1101/632976

Lamichhane, J R, Debaeke, P., Champolivier, L., Maury, P., 2020b. Combining experimental and modeling approaches to pinpoint genotype $\mathrm{x}$ sowing date $\mathrm{x}$ environment interaction effects on the quality of soybean establishment and grain yield. Fontiers Plant Sci. 11:558855. doi: 10.3389/fpls.2020.558855

Lamichhane, Jay Ram, You, M.P., Barbetti, M.J., Aubertot, J.-N., 2020c. Crop Establishment SIMulator: a qualitative aggregative model to predict the role of phytobiomes on field crop establishment. Phytobiomes J. https://doi.org/10.1094/PBIOMES-05-20-0036-R

Masuda, T., Goldsmith, P.D., 2009. Masuda, T., Goldsmith, P.D., 2009. World soybean production: area harvested,yield, and long-term projections. Int. Food Agribus. Manag. Rev. 12, 143-162.

McKee, S., Anderson, A., Carlisle, K., Shwiff, S.A., 2020. Economic estimates of invasive wild pig damage to crops in 12 US states. Crop Prot. 132, 105105. https://doi.org/https://doi.org/10.1016/j.cropro.2020.105105

Myllymaki, A., 1989. Denmark-Tanzania Rodent Control ProjectĐFinal Report (unpublished), Rodent Control Centre, Morogoro, Tanzania.

Nasu, H., Matsuda, L., 1976. The damage to soybean by pigeons and doves and itscontrol methods. Agr. Hort. 51, 563-566.

Sausse, C., Lévy, M., 2020. Dégâts d'oiseaux au tournesol: situation internationale et perspectives. OCL In press (in French).

Schillinger, W.F., Werner, S.J., 2016. Horned lark damage to pre-emerged canola seedlings. Ind. Crops Prod. 89, 465-467. https://doi.org/https://doi.org/10.1016/j.indcrop.2016.05.045

Sellers, L.A., Long, R.F., Jay-Russell, M.T., Li, X., Atwill, E.R., Engeman, R.M., Baldwin, R.A., 2018. Impact of field-edge habitat on mammalian wildlife abundance, distribution, and vectored foodborne pathogens in adjacent crops. Crop Prot. 108, 1-11. https://doi.org/https://doi.org/10.1016/j.cropro.2018.02.005

Swanepoel, L.H., Swanepoel, C.M., Brown, P.R., Eiseb, S.J., Goodman, S.M., Keith, M., Kirsten, F., Leirs, H., Mahlaba, T.A.M., Makundi, R.H., Malebane, P., von Maltitz, E.F., Massawe, A.W., Monadjem, A., Mulungu, L.S., Singleton, G.R., Taylor, P.J., Soarimalala, V., Belmain, S.R., 2017. A systematic review of rodent pest research in Afro-Malagasy small-holder farming systems: Are we asking the right questions? PLoS One 12, e0174554. https://doi.org/10.1371/journal.pone.0174554 
364 Werner, S.J., DeLiberto, S.T., Mangan, A.M., Pettit, S.E., Ellis, J.W., Carlson, J.C., 2015. 365 Anthraquinone-based repellent for horned larks, great-tailed grackles, American 366 crows and the protection of California's specialty crops. Crop Prot. 72, 158-162. https://doi.org/https://doi.org/10.1016/j.cropro.2015.03.020

368 Wise, K., 2018. Open Field Study with “Avipel Shield” Seed Treatment on Field Corn to 369 Deter Birds from Feeding on Corn Seed and Corn Seedlings. 370 https://hdl.handle.net/1813/48036 


\section{Table $\mathbf{1}$ (on next page)}

Key description of the field plots used for the observational study 
3 Table 1. Key description of the field plots used for the observational study

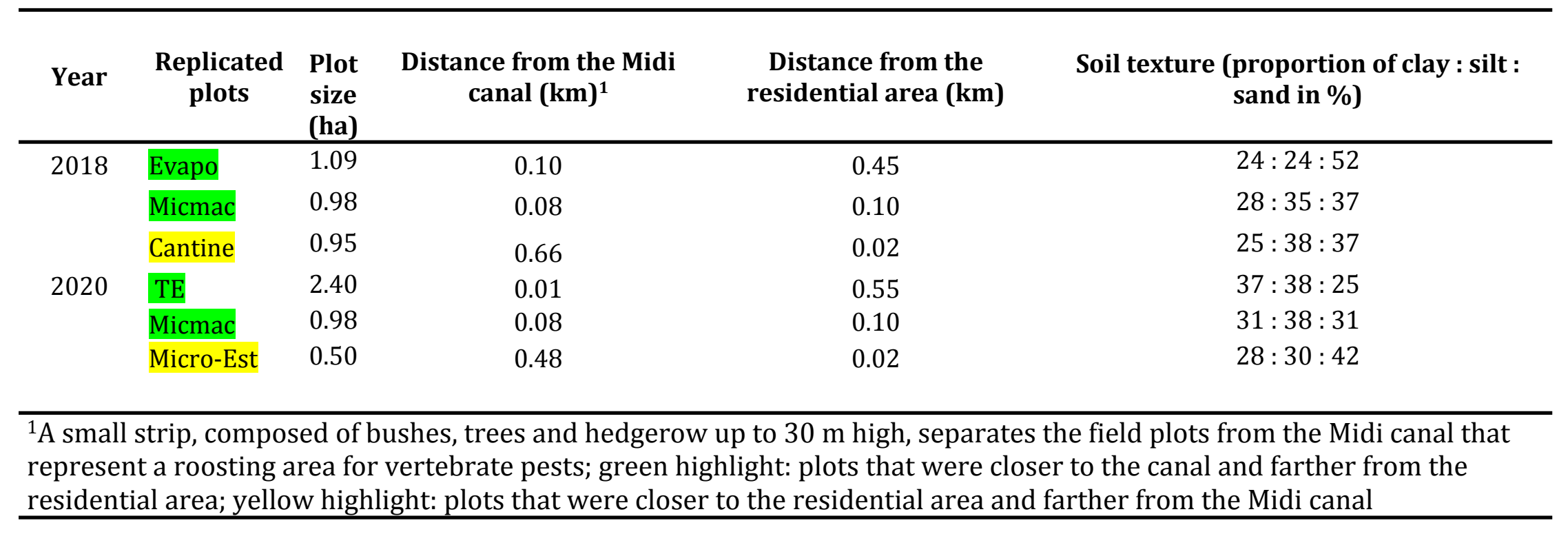




\section{Table 2 (on next page)}

Average final emergence rate ( \pm standard deviation) of soybean (cv. ES Pallador) in relation to spatio-temporal replication of field plots 
3 Table 2. Average final emergence rate $( \pm$ standard deviation) of soybean (cv. ES Pallador) in relation to spatio-temporal 4 replication of field plots

\begin{tabular}{ccc}
\hline Year & Plot & Emergence (\% \pm SD) \\
\hline 2018 & Evapo & $82^{\mathrm{b}} \pm 12$ \\
& Micmac & $72^{\mathrm{a}} \pm 13$ \\
\hline
\end{tabular}

Means followed by the different letter are significantly different at $\mathrm{p}<0.05$

6 


\section{Table 3 (on next page)}

Post emergence damage ( \pm standard deviation) caused by the common wood pigeon and the European hare on soybean 
1 Table 3. Post emergence damage ( \pm standard deviation) caused by the common wood pigeon and the European hare on 2 soybean

3

\begin{tabular}{ccccc}
\hline Year & $\begin{array}{c}\text { Partially-damaged } \\
\text { cotyledons (\%) }\end{array}$ & $\begin{array}{c}\text { Uprooted } \\
\text { seedlings (\%) }\end{array}$ & $\begin{array}{c}\text { Chewed } \\
\text { plantlets (\%) }\end{array}$ & Total damage (\%) \\
\hline 2018 & $12 \pm 4$ & $20 \pm 9$ & $18 \pm 14$ & $50 \pm 15$ \\
2020 & $8 \pm 3$ & $14 \pm 7$ & $17 \pm 10$ & $39 \pm 16$ \\
$p$ & $* * *$ & $* * *$ & $\mathrm{NS}$ & $* * *$ \\
\hline
\end{tabular}

NS: not significant; ${ }^{* * *} p<0.001$ 
Figure 1

An aerial view of the experimental site. The areas delimited in red and yellow represent the location of the field plots entirely sown with soybean, in 2018 and 2020, respectively. The information reported next to the delimited areas represent the histori 


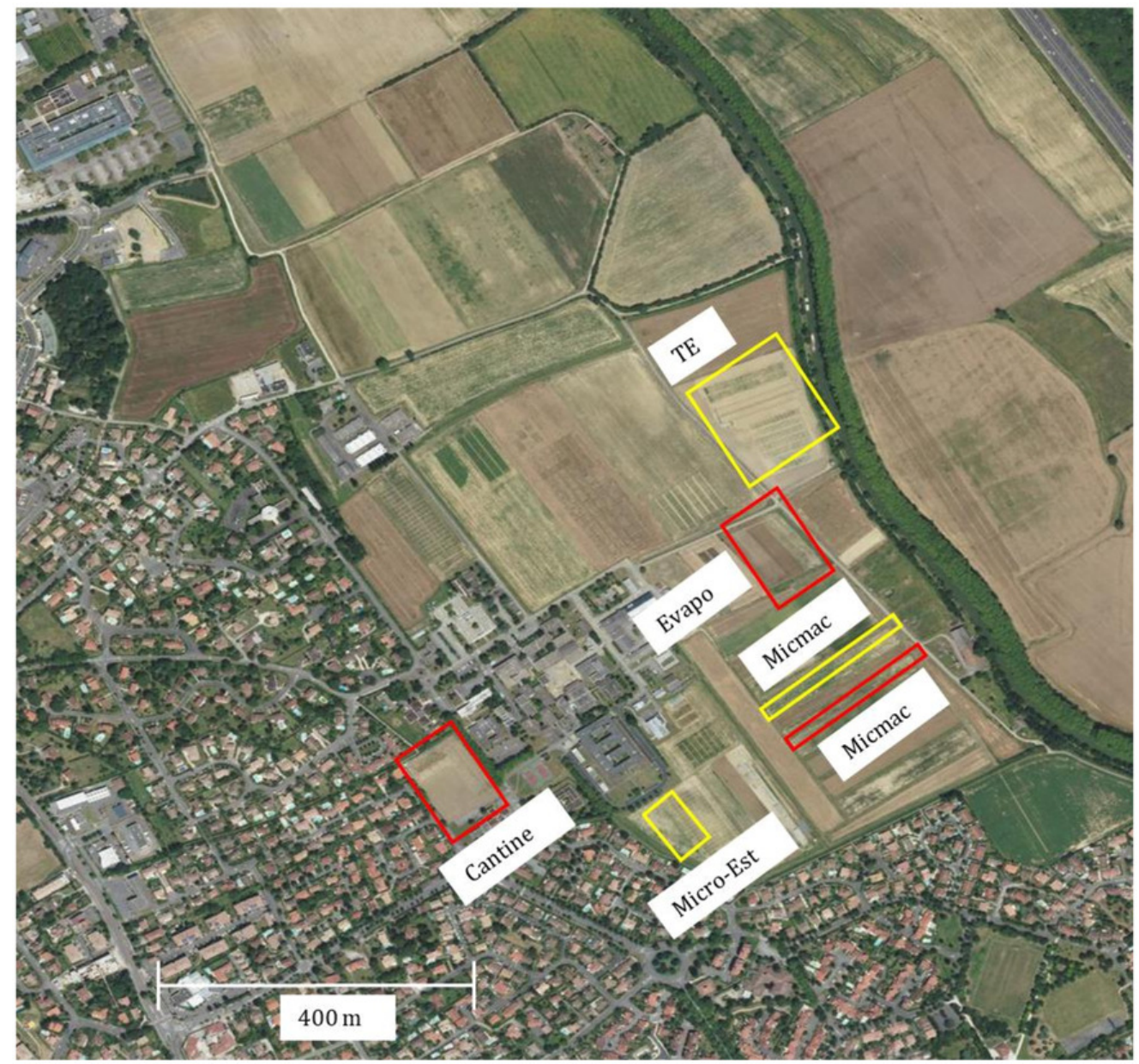


Figure 2

Study design used for the observational study at the scale of spatial replication (i.e. plot level) for countings of post-emergence seedling damage due to vertebrate pests. Following band sowing, each field plot was divided into four micro plots (M1 to M4 


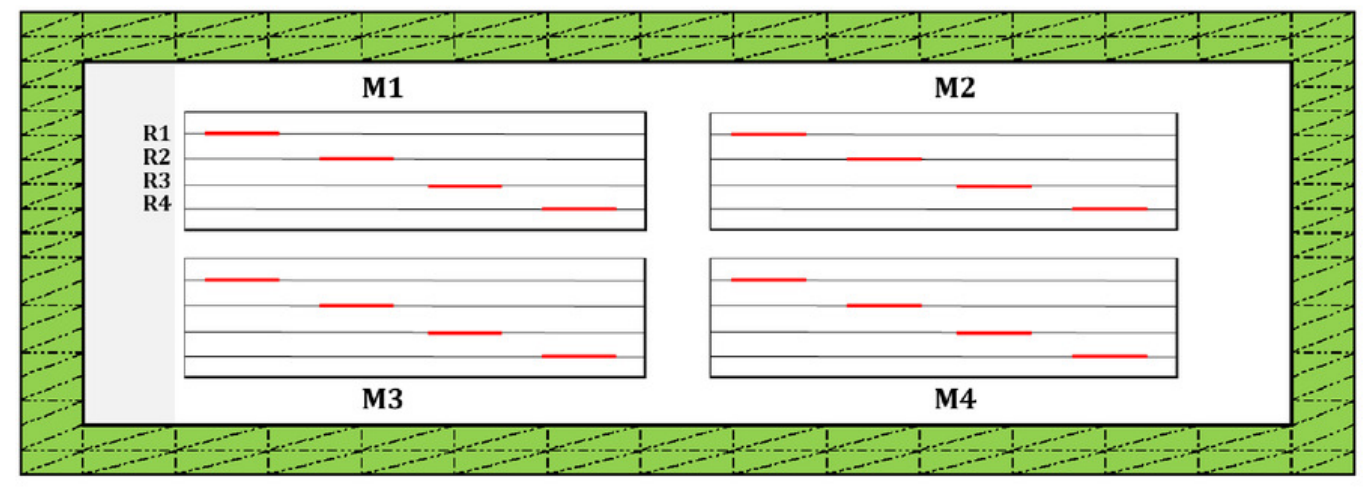


Figure 3

Characteristic post-emergence seedling damages caused by the common wood pigeon $(a, b)$ and the European hare ( $c, d)$ on soybean. The cotyledons can be partially damaged by birds during the emergence phase (a) or the entire seedling can be uprooted and scat 


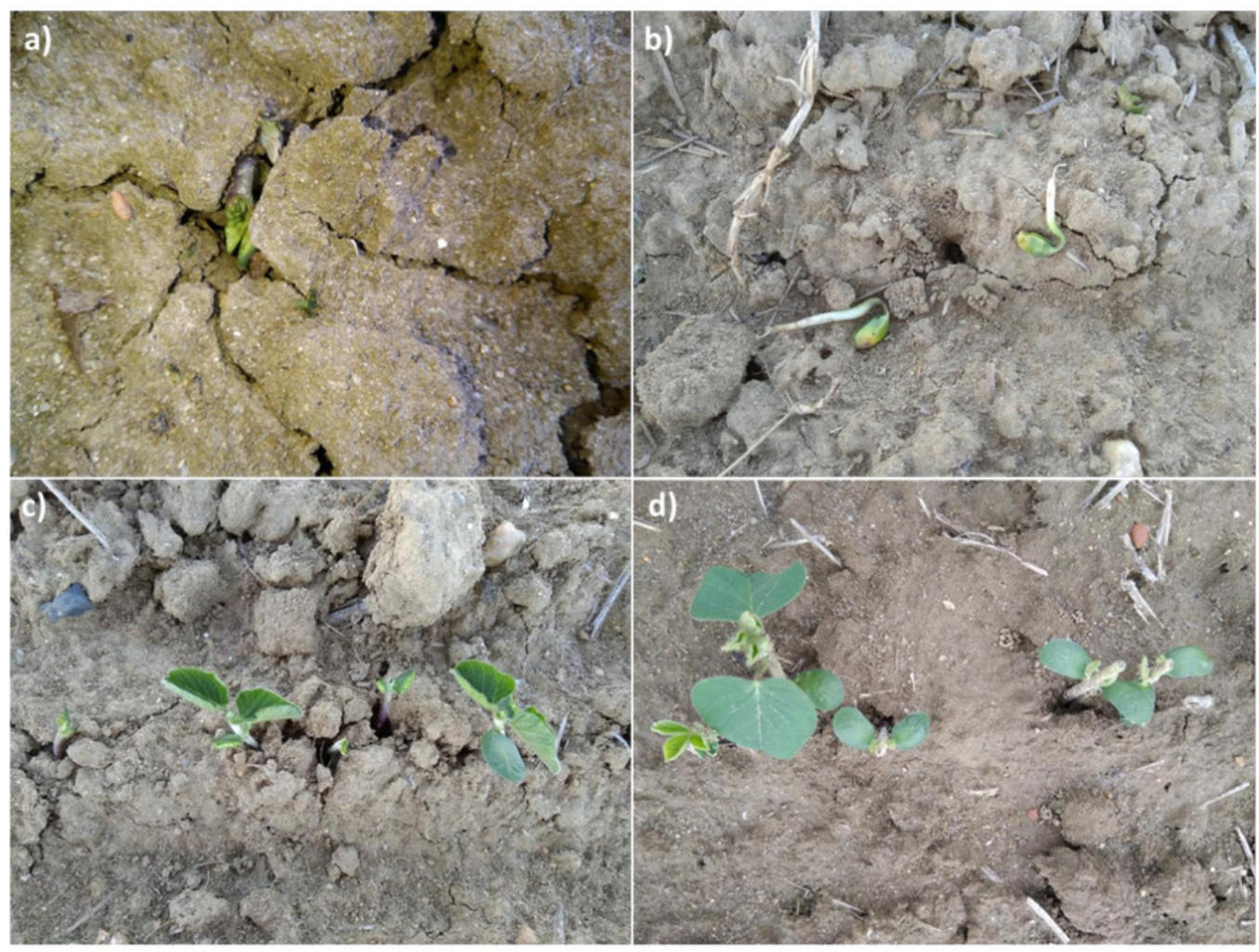


Figure 4

Post-emergence seedling damage due to the common wood pigeon can lead to total crop establishment failure with severe direct (re-sowing costs, yield losses) and indirect (increased weed pressure during the cropping season with increased weed seedbank for 


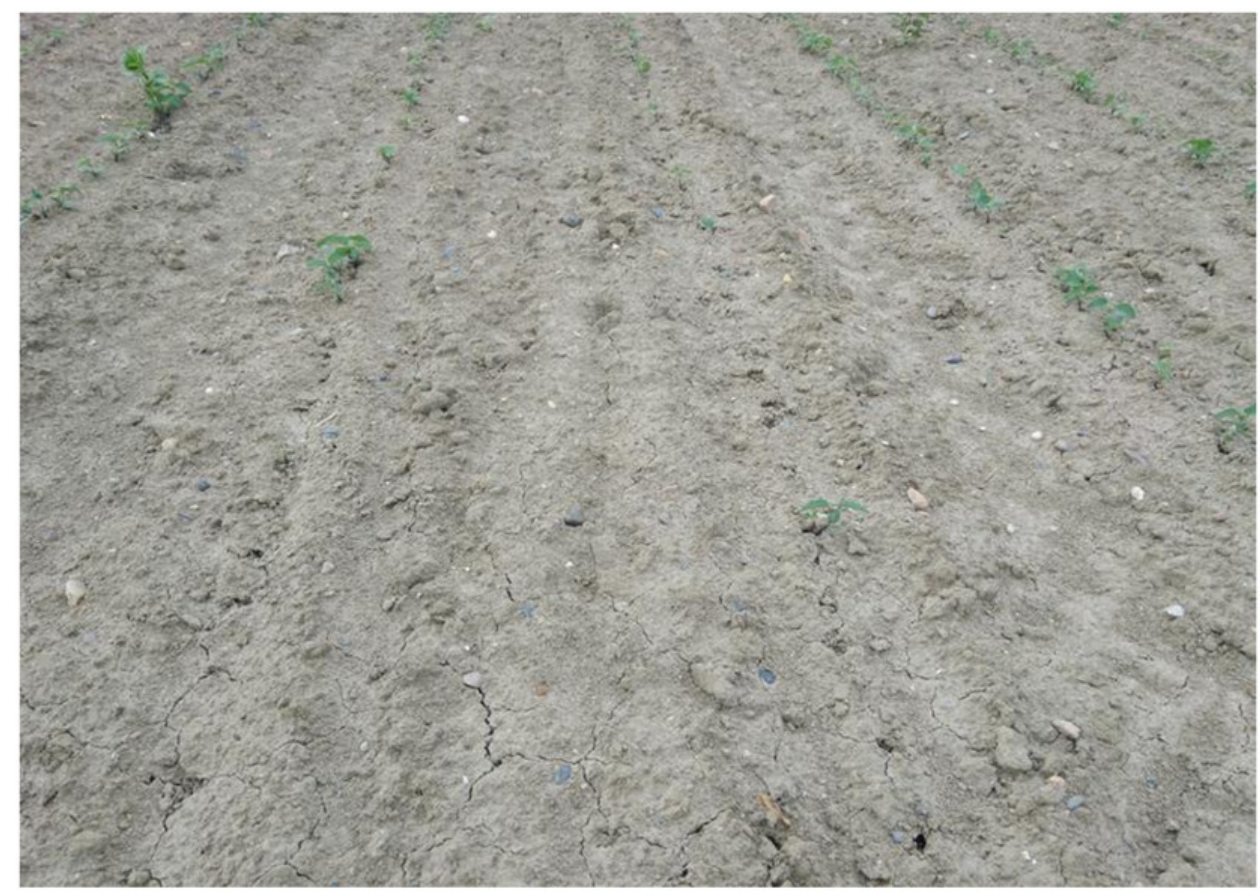


Figure 5

Heterogeneous growth stage of soybean seedlings due to post-emergence seedling damage by vertebrate pests. Damaged seedlings partly compensate their growth that mainly depends on the pest type and growth stage during which the damage occurred. 


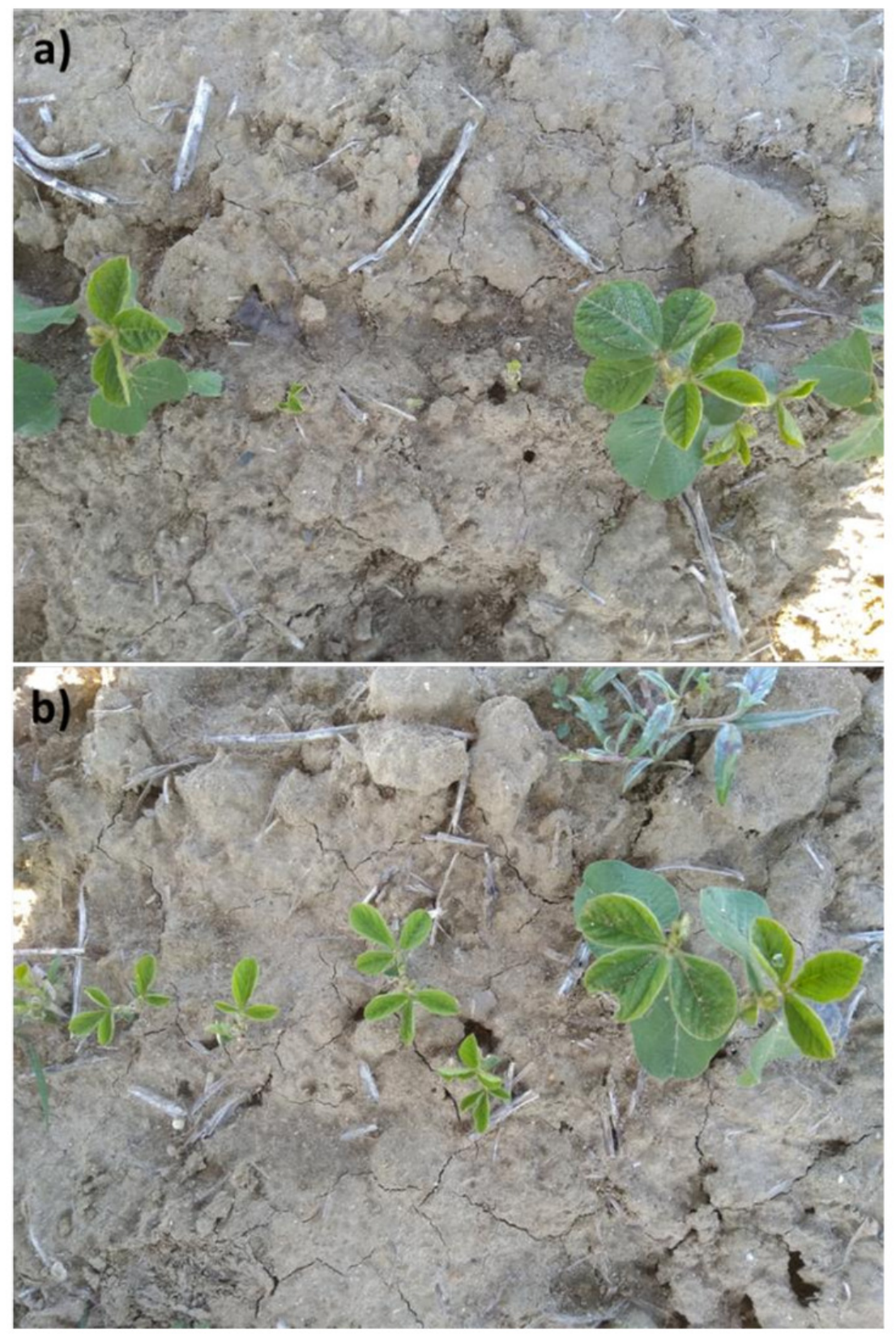

